\title{
Review
}

\section{Comparative analysis of multiparametric magnetic resonance and PET-CT in the management of local recurrence after radical prostatectomy for prostate cancer}

\author{
Andrea Alfarone ${ }^{\mathrm{a}}$, Valeria Panebianco ${ }^{\mathrm{b}}$, Orazio Schillaci ${ }^{\mathrm{c}}$, Stefano Salciccia ${ }^{\mathrm{a}}$, \\ Susanna Cattarino ${ }^{\mathrm{a}}$, Gianna Mariotti ${ }^{\mathrm{a}}$, Alessandro Gentilucci ${ }^{\mathrm{a}}$, Magnus Von Heland ${ }^{\mathrm{a}}$, \\ Roberto Passariello ${ }^{\mathrm{b}}$, Vincenzo Gentile ${ }^{\mathrm{a}}$, Alessandro Sciarra ${ }^{\mathrm{a}, *}$ \\ a Department Urology, University sapienza, Rome, Italy \\ b Department Radiology, University sapienza, Rome, Italy \\ c Department of Biopathology and Diagnostic Imaging, University of Rome “Tor Vergata” and IRCCS Neuromed, pozzilli, Italy
}

Accepted 25 January 2012

\section{Contents}

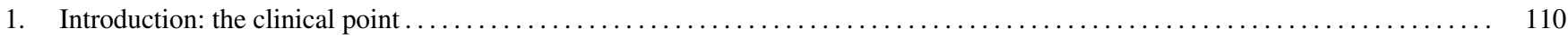

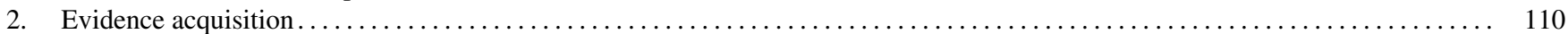

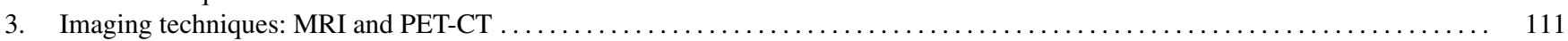

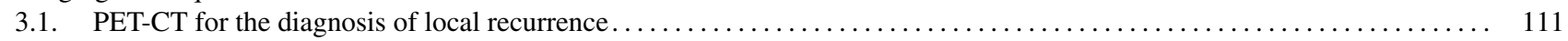

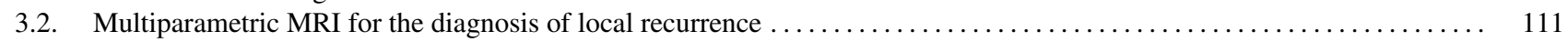

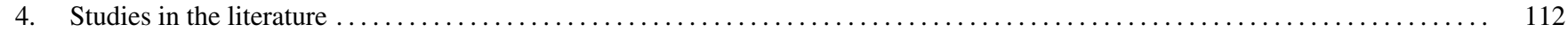

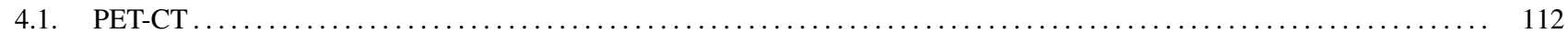

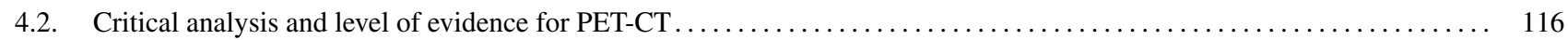

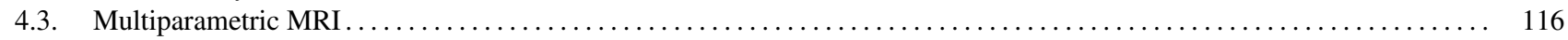

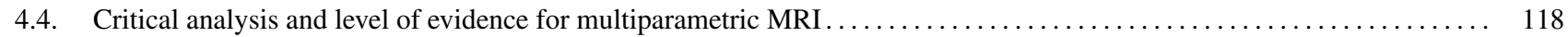

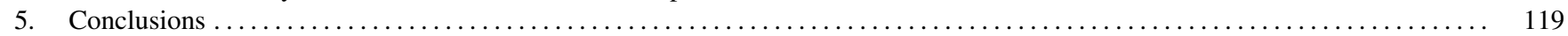

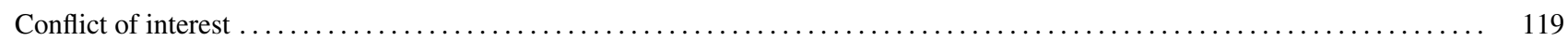

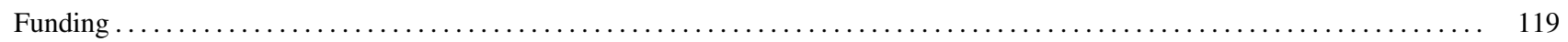

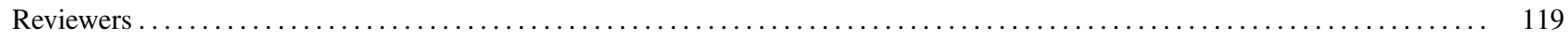

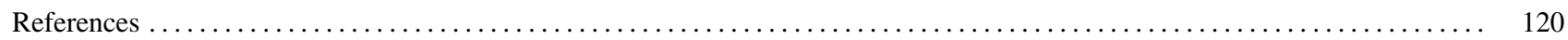

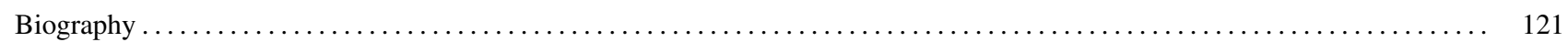

\begin{abstract}
Purpose: Our aim was to assess whether multiparametric magnetic resonance and PET-CT can have a role in detecting local recurrence in patients with biochemical recurrence after radical prostatectomy.

Methods: We reviewed the recent international literature by carrying out a PUBMED search.

Results: We critically reviewed 11 recent original studies about the use of PET-CT and 5 recent studies about the use of multiparametric magnetic resonance. PET-CT has not shown significant results in terms of detection rate for local recurrence in patients with low level of PSA. Multiparametric magnetic resonance showed encouraging results to detect local recurrence in patients with low PSA and with small diameter lesions.
\end{abstract}

\footnotetext{
* Corresponding author at: Prostate Cancer Unit, Department Urology, Policlinico Umberto I, University sapienza, Viale Policlinico 155, 00161 Rome, Italy.

E-mail addresses: sciarrajr@hotmail.com, sciarra.md@libero.it (A. Sciarra).
} 
Conclusions: Currently, most important urological societies do not consider multiparametric magnetic resonance and PET-CT in the follow-up of patients with suspected local recurrence after radical prostatectomy. We can assert that multiparametric magnetic resonance seems to have excellent results in detecting local recurrence in patients submitted to radical prostatectomy and PSA $<1.5 \mathrm{ng} / \mathrm{ml}$.

(C) 2012 Elsevier Ireland Ltd. All rights reserved.

Keywords: Prostate neoplasm; Local recurrence; Radical prostatectomy; Imaging

\section{Introduction: the clinical point}

A persistently elevated PSA level after radical prostatectomy (RP) means that PSA producing tissue remained and this is generally thought to be residual cancer due to either micro-metastases that were not detected or are undetectable, or to residual disease in the pelvis possibly due to positive surgical margins [1-4]. Tumour recurrence is common after primary therapy, occurring in 20-50\% after RP during a 10 years follow-up [3,4], manifested by a rising PSA level, often without clinical or radiological evidence of disease. Moreover $16-35 \%$ of patients will receive second line treatments within 5 years from the initial therapy [5]. Freedland et al. [6] showed that biochemical recurrence precedes clinical recurrence of a median of 5 years and that time to biochemical recurrence represents a predictive value for cancer specific survival.

Treatment failure after RP is defined as a rising PSA level, in particular two consecutive values of PSA $>0.2 \mathrm{ng} / \mathrm{ml}$ appear to represent biochemical recurrent cancer [7-10]. Once PSA relapse has been diagnosed, it is of major importance to determine whether the recurrence has developed at local or at distant sites. For this reason the urologist must use some parameters that can help to differentiate from local to distant relapse. One parameter that is used is the time to PSA increase after surgery: if the PSA level develop within the first 2 years following surgery is more likely to be associated with distant recurrence [11]. PSA doubling time (DT) is a second used parameter: if PSA DT is $<4$ months might be associated with distant relapse, whereas a median PSA DT $>12$ months predicts local failure.

Other informations can be obtained from the pathological examination after RP. The TNM staging system of the International Union Against Cancer (UICC) recommends to report not only the location but also the extension of extraprostatic invasion because extension is related to the risk of recurrence [12]. For what concern the surgical margin status, even if there is insufficient evidence to prove a relationship between the extension of positive surgical margins and the risk of recurrence [12,13], surgical margin status is considered an independent risk factor for biochemical recurrence, particularly local recurrence.

The way of treatment for PSA recurrence after RP remains controversial and different therapeutic options are available: in the absence of metastatic disease a rising PSA level is interpreted as locally persistent or recurrent disease and salvage radiotherapy could theoretically control the local disease. However if metastatic disease is found, radiotherapy to the prostate bed would be unnecessary, with higher risk of morbidity for the patient. With the development of new radiotherapy modalities, nowadays there is the possibility to escalate the dose of radiation in areas of known disease recurrence, so that an accurate identification of local recurrence with imaging might improve results of tumour eradication $[14,15]$.

For all these reasons there is a strong need for imaging techniques able to recognize small recurrent lesions and to describe the nature of these (inflammation or scar tissue, healthy prostate tissue or residue of neoplastic tissue). These techniques should be able to detect residual disease when the PSA is very low $(<1 \mathrm{ng} / \mathrm{ml})$, so to early perform the right therapeutic plane. Nowadays several imaging techniques are available but they all have limitations and often fail to produce reliable results. Scattoni et al. [16] demonstrated that Trans-rectal Ultrasound (TRUS) guided biopsies to detect local recurrence after RP have a limited sensitivity of $25-54 \%$, particularly when the PSA is $<1.0 \mathrm{ng} / \mathrm{ml}$. Kane et al. [17] in a retrospective analysis concluded that patients with biochemical recurrence after RP have a low probability of a positive bone scan (9.4\%) or a positive CT scan (14.0\%) within 3 years of biochemical recurrence. Most patients with a positive bone scan have a high PSA level and a high PSA velocity.

In the last years new technological acquisitions have allowed the development of imaging techniques able to detect changing of cellular metabolism and angiogenesis, from healthy to cancer tissue. Multiparametric magnetic resonance imaging (MRI) and positron emission tomography/computed tomography (PET-CT), more than other imaging procedures, have been proposed as useful tools in the diagnosis of morphological and functional changes. Both methods have had promising results in the diagnosis of $\mathrm{PC}$, in particular of local recurrence of $\mathrm{PC}$ after primary therapy.

The aim of our review is to critically analyze and compare the current evidence of these two different techniques, multiparametric MRI and PET-CT, for the diagnosis of local recurrence after RP.

\section{Evidence acquisition}

We searched in the Medline and Cochrane Library databases (primary fields: prostate neoplasm and local recurrence after RP and MRI or PET-CT) without language restriction from the literature of the last 10 years. 
Table 1

Level of evidence according to European Association of Urology Guidelines.

\begin{tabular}{|c|c|}
\hline Level & Type of evidence \\
\hline $1 \mathrm{a}$ & Evidence obtained from meta-analysis of randomized trials \\
\hline $1 b$ & Evidence obtained from at least one randomized trial \\
\hline $2 \mathrm{a}$ & $\begin{array}{l}\text { Evidence obtained from one well-designed controlled study } \\
\text { without randomization }\end{array}$ \\
\hline $2 b$ & $\begin{array}{l}\text { Evidence obtained from at least one other type of well-designed } \\
\text { quasi experimental study }\end{array}$ \\
\hline 3 & $\begin{array}{l}\text { Evidence obtained from well-designed non-experimental } \\
\text { studies, such as comparative studies, correlation studies and } \\
\text { case reports }\end{array}$ \\
\hline 4 & $\begin{array}{l}\text { Evidence obtained from expert committee reports or opinions } \\
\text { or clinical experience of respected authorities }\end{array}$ \\
\hline
\end{tabular}

Original articles and review articles, were included and clinically reviewed. Additional references were identified from reference lists of these articles. We have not included editorials, abstracts and reports from meetings. We included in the present review only articles specifically and primarily focused on the role of MRI or PET-CT in the detection of local recurrence after RP. For all studies we critically evaluated the level of evidence according to European Association of Urology (EAU) guidelines [18] (Table 1). In our research we have found 15 original studies on the use of PET-CT and 5 studies on the use of MRI, primarily focused on the detection of recurrence after primary therapy, in particular RP. In order to obtain a better comparison between the two different imaging procedures we particularly included in the analysis studies who clearly reported data on local recurrence detection rate, PSA level, number of patients submitted to RP and validation criteria for the imaging findings confirmation.

\section{Imaging techniques: MRI and PET-CT}

In recent years, new cellular biology acquisitions permit to better understand different tumour metabolism. Imaging technological improvements give the possibility to perform imaging procedures that combine anatomic, biologic and functional information. Both MRI and PET-CT nowadays are able to detect differences of cellular metabolites; the MRI with spectroscopy shows the relative concentrations of metabolites in the prostate as choline, citrate and creatine. PET-CT is able to visualize cellular metabolism using different radiotracers: Fluorodeoxyglucose (FDG), 11C metionine, $11 \mathrm{C}$ acetate, $11 \mathrm{C}$ and $18 \mathrm{~F}$ choline. The large amount of literature shows that choline is not only the most analysed metabolite, but probably the most useful for the identification of prostate tumour cells [19-21]. The aim of metabolic imaging should be to have an optimal spatial resolution so to detect very small lesions like local recurrences after RP, particularly in patients with biochemical failure and very low levels of PSA.

\subsection{PET-CT for the diagnosis of local recurrence}

The technique positron emission tomography (PET) is a molecular imaging that is able to create images from physiological and metabolic processes. PET use positron emitters to create quantitative tomographic images. PET images are volumetric set of data that can be displayed as tomographic images in the transaxial, coronal or sagittal planes. At the same time PET has a limitation: the lack of an anatomical reference frame. For this reason the combination of PET with the computerized tomography (CT) offers optimal fusion of images with an excellent morphological imaging with anatomical resolution.

Malignant tumours are usually characterized by enhanced glucose use. Increased fluorodeoxyglucose (FDG) use is correlated with increased cellular proliferation in tumours and this can be imaged by PET and 18F-FDG. However FDG in PC is a challenge, because of urinary excretion and low uptake. For this reason new PET tracers have been investigated in recent years. One of these new tracers is the choline, a substrate for the synthesis of phosphatidylcholine which is the major phospholipid in the cell membrane [19]. Choline has been the most used tracer to study PC with PET-CT [22]. A target of the PET-CT procedure is the possibility to show with good sensitivity the staging of the disease in the whole body in one step.

\subsection{Multiparametric MRI for the diagnosis of local recurrence}

In the last 20 years several progresses have been done in the use of MRI. Endorectal coil MRI is able to produce a morphological imaging of the prostate, particularly T2 weighted (T2w) MRI [23]. Other recent complementary techniques improve the staging and the detection of PC. Dynamic contrast-enhanced MRI (DCE-MRI) is a technique based on the assessment of neoangiogenesis, therefore it can detect those tumours in which an angiogenic pathway has been turned on [24]. T1 weighted (T1w) sequences are used during the passage of a contrast agent within the prostatic tissue. The peri-anastomotic fibrosis appears hypointense on T2 weighted images, with absent enhancement on DCE-MRI. After DCE-MRI all benign nodules show signal enhancement of less than 50\% in the early phase, whereas all recurrences showed fast signal enhancement in the early phase followed by a plateau or washout. Recurrences appear as masses with intermediate signal intensity on $\mathrm{T} 2$ weighted images, enhancing after intravenous injection of contrast medium.

Diffusion weighted magnetic resonance imaging (DWMRI) yields qualitative and quantitative information about tissue cellularity and cell membrane integrity and proton diffusion properties within water are used to obtain image contrast. Intraductal and extracellular water molecules move freely. In PC extracellular space is decreased, therefore the water molecule movement is restricted and the so-called apparent diffusion coefficient values are low. DW-MRI can 
be produced without the administration of exogenous contrast medium and can be considered the most practical and simple to use [25].

Magnetic resonance spectroscopic imaging (MRSI) is a three dimensional data set of the prostate, with volume elements (voxels) ranging from $0.24 \mathrm{~cm}$ to $0.34 \mathrm{~cm} \mathrm{[26]} \mathrm{This}$ technique produces the relative concentration of metabolites within voxels, such as citrate, choline and creatine. Recent studies demonstrate that in PC citrate levels are reduced, creatine and particularly choline are elevated. The ratio of choline plus creatine to citrate can distinguish from PC tissue to healthy tissue [27]. On the basis of the literature each voxel can be categorized as follows: fibrotic or scar tissue when the ratio is $<0.2$, residual healthy prostatic gland tissue when ratio is $>0.2$ and $<0.5$, probably recurrent $\mathrm{PC}$ when ratio is $>0.5$ and $<1$; definitively recurrent $\mathrm{PC}$ tissue when ratio is $>1$ [28]. MRSI technique is more complex when compared with DWI or DCE-MRI and it also requires longer acquisition times.

Multiparametric MRI has the advantage to have a very good spatial resolution so to localise and characterise PC, to detect very small lesions and to better differentiate from healthy to neoplastic areas. It is a complex technique and needs experienced and trained radiologists, in particular if we consider the MRSI. Multiparametric MRI does not have at now a large availability in hospitals, it is a procedure that requires time and it does not have good detection rates for nodal and distant metastasis.

\section{Studies in the literature}

\subsection{PET-CT}

Of all studies reviewed on the use of PET-CT, we particularly describe 11 articles that appeared to be the most extensive in terms of data on local recurrence following RP.

A single-centre retrospective study from Heinisch et al. [29] suggested that using 18F-choline PET-CT is possible to have positive findings in patients with biochemical progression after RP, also with PSA level $<5 \mathrm{ng} / \mathrm{ml}$. In this study the results of PET-CT were mostly compared with other imaging modalities (CT and/or MRI), and only in few cases local tumour progression was histologically confirmed at biopsy, as well as the course of disease was clinically defined. They analysed 31 patients after RP and they found that $8 / 17$ patients $(47 \%)$ with biochemical recurrence and with PSA $<5 \mathrm{ng} / \mathrm{ml}$, had positive results at $18 \mathrm{~F}$-choline PET-CT. In their analysis they found malignancy in $7 / 8$ men positive at PET-CT exam and with a PSA $<5 \mathrm{ng} / \mathrm{ml}$, confirmed by either correlating imaging methods (CT and/or MR), biopsy/histology, or the course of the disease. Median PSA in 18F-choline PET-CT positive patients was $6.1 \mathrm{ng} / \mathrm{ml}$ (mean PSA $17.1 \mathrm{ng} / \mathrm{ml}$ ) and median PSA in 18F-choline PET-CT negative patients was $2.3 \mathrm{ng} / \mathrm{ml}$ (mean PSA $3.4 \mathrm{ng} / \mathrm{ml}$ ). In this study authors did not report other data about the detection rate of PET-CT particularly focused on prostate bed recurrences. At the same time they did not reported data on the maximal diameter of recurrence lesions. Statistical analysis in terms of sensitivity, specificity or accuracy is not provided (level of evidence 3; see Table 2).

In a single-centre retrospective study, Rinnab et al. [30] analysed 50 consecutive patients with biochemical recurrence after primary therapy for PC (RP in 40 patients), using $11 \mathrm{C}$ choline PET-CT. The results were correlated with a histopathology examination. Mean PSA serum levels were $3.62 \mathrm{ng} / \mathrm{ml}$ (range $0.5-13.1 \mathrm{ng} / \mathrm{ml}$ ) in patients with a positive PET-CT and $0.90 \mathrm{ng} / \mathrm{ml}$ (range $0.41-1.4 \mathrm{ng} / \mathrm{ml}$ ) in patients with negative PET-CT. Of 13 patients with a PSA $<1.5 \mathrm{ng} / \mathrm{ml}, 7$ had a positive PET-CT and in 9/13 histology was positive for PC recurrence. In 17 patients with PSA $>1.5<2.5 \mathrm{ng} / \mathrm{ml}$, all of them were positive at PETTC and 13/17 had a positive histology. In 11 patients with PSA $>2.5<5.0 \mathrm{ng} / \mathrm{ml}$, all had positive PET-CT and only $1 / 11$ had negative histology. The last group was composed by 9 patients with PSA $>5.0 \mathrm{ng} / \mathrm{ml}$ : also in this group all patients had positive PET-CT and only $1 / 9$ had a negative histology. The overall sensitivity of PET-CT for detecting recurrence was $95 \%$ and PPV was $86 \%$; the overall specificity was $40 \%$, NPV was $67 \%$ and the accuracy was $84 \%$. The authors also considered the sensitivity and specificity of PET-CT only in patients with PSA $<2.5 \mathrm{ng} / \mathrm{ml}$, reporting $91 \%$ and $50 \%$, respectively. Unfortunately authors did not determined the diameter of lesions (level of evidence $2 b$; see Table 2).

Vees et al. [31] in a multicentre retrospective study, evaluated 20 patients divided in two different groups with biochemical recurrence or suspected residual tumour after RP. In the first group they used $18 \mathrm{~F}$ choline PET-CT to detect local recurrence whereas in the second group they used 11C acetate PET-CT. Two patients were submitted to both PET-CT exams; therefore the study analysed 22 PET-CT exams. Only patients with a PSA level $<1.0 \mathrm{ng} / \mathrm{ml}$ (range $0.11-0.73 \mathrm{ng} / \mathrm{ml}$ ) were included. At PET-CT they found abnormal local tracer uptake in $5 / 10$ and $6 / 10$ patients, respectively in the two groups. Authors did not give more information regarding the maximal diameter of prostate bed lesions. As control they used endorectal coil MRI that was positive in 15/18 cases (2 patients did not perform MRI scan). All patients received salvage radiotherapy after PET-CT and a decrease by half in the PSA level after salvage radiotherapy was considered the endpoint of the response, confirming the presence of local disease. This endpoint was achieved in $8 / 10$ patients in the first group and in $7 / 10$ cases in the second group. They reported a sensitivity of $60 \%$ and $66 \%$ for $18 \mathrm{~F}$ choline PET-CT and $11 \mathrm{C}$ acetate PET-CT, respectively. Authors did not estimate specificity because there were too few patients with stable or increasing PSA after salvage radiotherapy. They summarized that PET-CT cannot be recommended as standard diagnostic tool for early relapse or suspicion of minimal persistent disease after surgery (level of evidence 3 , see Table 2). 
Table 2

Characteristics and level of evidence of the different reviewed studies on multiparametric MRI and PET-CT for the diagnosis of local recurrence after RP.

\begin{tabular}{|c|c|c|c|c|c|c|c|c|}
\hline Authors & Imaging used & Study & Number cases & Mean PSA & Mean lesion size & Validation used & $\begin{array}{l}\text { Sensibility, specificity, } \\
\text { PPV, NPV, accuracy }\end{array}$ & $\begin{array}{l}\text { Level of } \\
\text { evidence }\end{array}$ \\
\hline Heinisch [29] & $\begin{array}{l}18 \mathrm{~F} \text { choline } \\
\text { Pet-CT }\end{array}$ & Retrospective & 31 & $\begin{array}{l}17.1 \mathrm{ng} / \mathrm{ml} \text { in positive } \\
\text { pts }-3.4 \mathrm{ng} / \mathrm{ml} \text { in } \\
\text { negative pts }\end{array}$ & Not available & $\begin{array}{l}\text { CT-MRI-histology, course } \\
\text { of disease }\end{array}$ & Not available & 3 \\
\hline Rinnab [30] & & Retrospective & 40 & $\begin{array}{l}3.62 \mathrm{ng} / \mathrm{ml} \text { in positive } \\
\text { pts }-0.9 \mathrm{ng} / \mathrm{ml} \text { in } \\
\text { negative patients }\end{array}$ & Not available & Hystology & $\begin{array}{l}\text { Sensitivity } 95 \% \text {, } \\
\text { Specificity } 40 \% \text {, PPV } \\
86 \%, \text { NPV } 67 \% \text {, } \\
\text { Accuracy } 84 \%\end{array}$ & $2 b$ \\
\hline Vees [31] & $\begin{array}{l}18 \mathrm{~F} \text { choline } \\
\text { Pet-CT+ 11C } \\
\text { choline Pet-CT }\end{array}$ & Retrospective & 20 & $<1 \mathrm{ng} / \mathrm{ml}$ & Not available & $\begin{array}{l}\text { MRI, clinical validation } \\
\text { with PSA following } \\
\text { radiotherapy }\end{array}$ & $\begin{array}{l}\text { Sensitivity of } 18 \mathrm{~F} \text { choline } \\
60 \% \\
\text { Sensitivity of } 11 \mathrm{C} \text { choline } \\
66 \%\end{array}$ & 3 \\
\hline Reske [32] & $\begin{array}{l}11 \mathrm{C} \text { choline } \\
\text { Pet-CT }\end{array}$ & Retrospective & $\begin{array}{l}36+13 \text { control } \\
\text { group }\end{array}$ & $2 \mathrm{ng} / \mathrm{ml}$ & $1.7 \mathrm{~cm}$ & Hystology & $\begin{array}{l}\text { Sensitivity } 73 \% \text {, } \\
\text { Specificity } 88 \%, \text { PPV } \\
92 \%, \text { NPV } 61 \% \text {, } \\
\text { Accuracy } 78 \%\end{array}$ & $2 b$ \\
\hline Rinnab [33] & $\begin{array}{l}11 \mathrm{C} \text { choline } \\
\text { Pet-CT }\end{array}$ & Retrospective & 41 & $2.8 \mathrm{ng} / \mathrm{ml}$ & Not available & Hystology & $\begin{array}{l}\text { Sensitivity } 93 \% \text {, } \\
\text { Specificity 36\%, PPV } \\
80 \% \text {, NPV 67\% }\end{array}$ & $2 \mathrm{~b}$ \\
\hline Castellucci [34] & $\begin{array}{l}11 \mathrm{C} \text { choline } \\
\text { Pet-CT }\end{array}$ & Retrospective & 190 & $4.2 \mathrm{ng} / \mathrm{ml}$ & Not available & Hystology & $\begin{array}{l}\text { Sensitivity } 73 \% \\
\text { Specificity } 69 \%\end{array}$ & $2 \mathrm{~b}$ \\
\hline Giovacchini [35] & $\begin{array}{l}11 \mathrm{C} \text { choline } \\
\text { Pet-CT }\end{array}$ & Retrospective & 170 & $3.24 \mathrm{ng} / \mathrm{ml}$ & Not available & Not available & $\begin{array}{l}\text { Sensitivity } 87 \% \text {, } \\
\text { Specificity } 89 \% \text {, PPV } \\
87 \% \text {, NPV } 89 \% \text {, } \\
\text { Accuracy } 88 \%\end{array}$ & $2 b$ \\
\hline Giovacchini [36] & $\begin{array}{l}11 \mathrm{C} \text { choline } \\
\text { Pet-CT }\end{array}$ & Retrospective & 358 & $3.77 \mathrm{ng} / \mathrm{ml}$ & Not available & $\begin{array}{l}\text { Hystology or clinical } \\
\text { validation with PSA } \\
\text { following radiotherapy }\end{array}$ & $\begin{array}{l}\text { Sensitivity } 85 \% \text {, } \\
\text { Specificity } 93 \% \text {, PPV } \\
91 \% \text {, NPV } 87 \% \text {, } \\
\text { Accuracy } 89 \%\end{array}$ & $2 b$ \\
\hline Giovacchini [37] & $\begin{array}{l}11 \mathrm{C} \text { choline } \\
\text { Pet-CT }\end{array}$ & Retrospective & 109 & $1.31 \mathrm{ng} / \mathrm{ml}$ & $\begin{array}{l}8.7 \mathrm{~mm} \text { for nodal } \\
\text { lesions, not } \\
\text { available for } \\
\text { prostatectomy bed } \\
\text { recurrences }\end{array}$ & Hystology & Not available & $2 b$ \\
\hline Castellucci [38] & $\begin{array}{l}11 \mathrm{C} \text { choline } \\
\text { Pet-CT }\end{array}$ & Retrospective & 102 & $<1.5$ & Not available & Hystology & $\begin{array}{l}\text { Sensitivity } 53 \% \\
\text { Specificity } 100 \%\end{array}$ & $2 \mathrm{a}$ \\
\hline Sella [40] & Endorectal MRI & Retrospective & 48 & $2.18 \mathrm{ng} / \mathrm{ml}$ & $1.4 \mathrm{~cm}$ & $\begin{array}{l}\text { Hystology or clinical } \\
\text { validation with PSA } \\
\text { following radiotherapy or } \\
\text { follow up with MRI }\end{array}$ & $\begin{array}{l}\text { Sensitivity } 95 \% \\
\text { Specificity } 100 \%\end{array}$ & $2 b$ \\
\hline
\end{tabular}


Table 2 (Continued)

\begin{tabular}{|c|c|c|c|c|c|c|c|c|}
\hline Authors & Imaging used & Study & Number cases & Mean PSA & Mean lesion size & Validation used & $\begin{array}{l}\text { Sensibility, specificity, } \\
\text { PPV, NPV, accuracy }\end{array}$ & $\begin{array}{l}\text { Level of } \\
\text { evidence }\end{array}$ \\
\hline Casciani [41] & MRI with DCE & Retrospective & 46 & $1.9 \mathrm{ng} / \mathrm{ml}$ & $1.5 \mathrm{~cm}$ & $\begin{array}{l}\text { Hystology or clinical } \\
\text { validation with PSA } \\
\text { following radiotherapy }\end{array}$ & $\begin{array}{l}\text { Sensitivity } 88 \%, \\
\text { Specificity } 100 \% \text {, PPV } \\
100 \%, \text { NPV } 88 \%, \\
\text { Accuracy } 94 \%\end{array}$ & $2 b$ \\
\hline Sciarra [42] & MRSI + DCEMRI & Prospectic & $\begin{array}{l}77(10 \text { pts as } \\
\text { control })\end{array}$ & $\begin{array}{l}1.26 \mathrm{ng} / \mathrm{ml} \text { in group A } \\
0.8 \mathrm{ng} / \mathrm{ml} \text { in group B }\end{array}$ & $\begin{array}{l}13.3 \mathrm{~mm} \text { in group } \\
\text { A } 6 \mathrm{~mm} \text { in group } \\
\text { B }\end{array}$ & $\begin{array}{l}\text { Hystology (group A) or } \\
\text { clinical validation with } \\
\text { PSA following } \\
\text { radiotherapy (Group B) }\end{array}$ & $\begin{array}{l}\text { In Group A Sensitivity } \\
87 \% \text {, Specificity } 94 \% \text {, } \\
\text { PPV } 96 \% \text {, NPV } 79 \% \\
\text { In Group B Sensitivity } \\
86 \% \text {, Specificity 100\%, } \\
\text { PPV 100\%, NPV } 75 \%\end{array}$ & $2 \mathrm{a}$ \\
\hline Cirillo [43] & CE-MRI & Retrospective & 72 & $1.23 \mathrm{ng} / \mathrm{ml}$ & $1.7 \mathrm{~cm}$ & $\begin{array}{l}\text { Hystology, choline } \\
\text { PET-CT, follow up with } \\
\text { PSA }\end{array}$ & $\begin{array}{l}\text { Sensitivity } 84.1 \% \text {, } \\
\text { Specificity } 89.3 \% \text {, PPV } \\
92.5 \% \text {, NPV } 78.1 \% \text {, } \\
\text { Accuracy } 86.1 \%\end{array}$ & $2 \mathrm{a}$ \\
\hline Panebianco [44] & $\begin{array}{l}\text { MRSI + DCEMRI } \\
\text { and } 18 \text { F choline } \\
\text { Pet-CT }\end{array}$ & Prospectic & 84 & $\begin{array}{l}1.1 \mathrm{ng} / \mathrm{ml} \text { in group A } \\
1.9 \mathrm{ng} / \mathrm{ml} \text { in group B }\end{array}$ & $\begin{array}{l}6 \mathrm{~mm} \text { in group A } \\
13.3 \mathrm{~mm} \text { in group } \\
\mathrm{B}\end{array}$ & $\begin{array}{l}\text { Hystology (group B) or } \\
\text { clinical validation with } \\
\text { PSA following } \\
\text { radiotherapy (Group A) }\end{array}$ & $\begin{array}{l}\text { In Group A with MRI } \\
\text { Sensitivity 92\%, } \\
\text { Specificity 75\%, PPV } \\
\text { 96\%, NPV 60\%, } \\
\text { Accuracy } 89 \% \\
\text { In Group A with PET-CT } \\
\text { Sensitivity } 62 \% \text {, } \\
\text { Specificity 50\%, PPV } \\
88 \% \text {, NPV 18\%, } \\
\text { Accuracy 60\% } \\
\text { In Group B with MRI } \\
\text { Sensitivity 94\%, } \\
\text { Specificity 100\%, PPV } \\
\text { 100\%, NPV 57\%, } \\
\text { Accuracy 94\%, } \\
\text { In Group B with PET-CT } \\
\text { Sensitivity 92\%, } \\
\text { Specificity 37\%, PPV } \\
\text { 98\%, NPV 43\%, } \\
\text { Accuracy } 91 \%\end{array}$ & $2 \mathrm{a}$ \\
\hline
\end{tabular}


Reske et al. [32] in a single-centre retrospective study, analysed 49 patients into two groups. The group A included 36 patients with biochemical recurrence after RP and the group B (control group) 13 patients submitted to RP without biochemical relapse. All patients enrolled in this study had a 11C choline PET-CT examination. In group A mean PSA levels at the day of the exam was $2.0 \mathrm{ng} / \mathrm{ml}$ (range $0.3-12.1 \mathrm{ng} / \mathrm{ml}$ ). A TRUS-guided biopsy of the prostate bed showed local recurrence $\mathrm{PC}$ at histology in 33 cases and only scar tissue in 3 cases. 11C choline PET-CT was positive in 23/33 (70\%) patients with histological confirmation of local recurrence disease and in one of the 3 patients without histological confirmation of PC. The median maximal diameter of PET-CT lesions was $1.7 \mathrm{~cm}$ (range $0.9-3.7 \mathrm{~cm}$ ). In the control group only $1 / 13$ patient was positive at PET-CT exam. They concluded that $11 \mathrm{C}$ choline PET-CT had a sensitivity of $73 \%$, specificity $88 \%$, Positive Predictive Value (PPV) 92\%, Negative Predictive Value (NPV) $61 \%$ and an accuracy of $78 \%$ (level of evidence $2 b$, see Table 2 ).

In a recent single-centre retrospective study, Rinnab et al. [33] enrolled 41 patients with biochemical failure following RP (9/41 patients received an adjuvant treatment with radiotherapy). All patients were submitted to $11 \mathrm{C}$ choline PET-CT and then, in cases with suspected local recurrences, a TRUSguided biopsy was performed. Mean PSA was $2.8 \mathrm{ng} / \mathrm{ml}$ (range $0.41-11.6 \mathrm{ng} / \mathrm{ml}$ ) for all the population, $3.1 \mathrm{ng} / \mathrm{ml}$ in patients with positive findings and $0.86 \mathrm{ng} / \mathrm{ml}$ in patients with negative findings. Authors divided the population on the basis of PSA levels so to analyse PET-CT detection rate in each group. Overall the sensitivity of PET-CT was $93 \%$, specificity $36 \%$, PPV $80 \%$, NPV $67 \%$. In the group of cases (12 patients) with a PSA $<1.5 \mathrm{ng} / \mathrm{ml}$ sensitivity was $67 \%$, specificity $67 \%$, PPV $67 \%$ and NPV $67 \%$. In the group of cases (28 patients) with a PSA $<2.5 \mathrm{ng} / \mathrm{ml}$ sensitivity was $89 \%$, specificity $72 \%$, PPV $40 \%$ and NPV 67\%. Authors did not reported specific data only for local recurrence and did not report diameters of local recurrence lesions (level of evidence $2 b$, see Table 2).

In single-centre retrospective study, Castellucci et al. [34] enrolled 190 patients previously treated with RP and with biochemical recurrence. All cases were analysed with 11C choline PET-CT and the mean PSA serum level was $4.2 \mathrm{ng} / \mathrm{ml}$ (range $0.2-25.4 \mathrm{ng} / \mathrm{ml}$ ). Patients were divided into 4 different groups on the basis of the PSA level: PSA $<1.0 \mathrm{ng} / \mathrm{ml}$ (51 patients), PSA $>1.0<2.0 \mathrm{ng} / \mathrm{ml}$ (39 patients), PSA $>2.0<5.0 \mathrm{ng} / \mathrm{ml}$ (51 patients) and PSA $>5.0 \mathrm{ng} / \mathrm{ml}$ (49 patients). PET-CT was positive in $74 / 190$ patients $(38.9 \%$ ), mean PSA value was $2.4 \mathrm{ng} / \mathrm{ml}$ in PET-TC negative and $6.7 \mathrm{ng} / \mathrm{ml}$ in PET-CT positive patients. The percentage of positive $11 \mathrm{C}$ choline PET-CT scans was $19 \%$ in the group of patients with $\mathrm{PSA}<1.0 \mathrm{ng} / \mathrm{ml}, 25 \%$ in patients with PSA $>1.0<2.0 \mathrm{ng} / \mathrm{ml}$, $41 \%$ in patients with PSA $>2.0<5.0 \mathrm{ng} / \mathrm{ml}$ and $67 \%$ in patients with PSA $>5.0 \mathrm{ng} / \mathrm{ml}$. The ROC analysis demonstrated an area under the curve (AUC) of 0.76 , a sensitivity of $73 \%$ and specificity of $69 \%$ for the prediction of PET$\mathrm{CT}$ in terms of recurrence positive results. The analysis also demonstrated an optimal cut-off value for PSA to indicate a PET-CT of $2.43 \mathrm{ng} / \mathrm{ml}$. Authors found that there were no false positive results at PET-CT. Unfortunately, of the 74 PET-CT positive patients, only 5 had a local recurrence disease validated at histology after a TRUS guided biopsy. Moreover, they did not reported any data about the dimension of the local recurrence lesion (level of evidence $2 b$, see Table 2).

In the first of three studies (retrospective single-centre), Giovacchini et al. [35] analysed 170 patients with biochemical failure after RP. All patients were submitted to $11 \mathrm{C}$ choline PET-CT, mean PSA serum level at the time of the exam was $3.24 \mathrm{ng} / \mathrm{ml}$ (range $0.23-48.6 \mathrm{ng} / \mathrm{ml}$ ) and mean PSA-DT was 9.37 months. In this study $44 \%$ of patients (75/170) had a positive PET-CT and these cases had significantly higher PSA levels and shorter PSA-DT. Only local recurrences at PET-CT were found in 24 patients, whereas other 12 patients had local recurrence with concomitant nodes or distant metastases. Including all patients, PET-CT showed a sensitivity of $87 \%$, specificity of $89 \%$, PPV of $87 \%$, NPV of $89 \%$ and accuracy of $88 \%$. They found 3 false positive and 7 false negative regarding the analysis of the prostatectomy bed. In this study PET-CT positive finding were confirmed using: histological analysis of lymph node specimen, vescicourethral anastomosis biopsy, progression on PET-CT follow-up studies associated with increased PSA level, confirmation with conventional imaging, disappearance or sizable reduction of choline uptake after local or systemic treatment, PSA decrease greater than $50 \%$ after selective irradiation of the unique site of pathological choline uptake. Authors did not explain how they specifically validated local recurrences and also they did not reported the diameters of recurrence lesions. In this study authors also proposed a nomogram to predict the probability of positive finding at $11 \mathrm{C}$ choline PET-CT (level of evidence $2 \mathrm{~b}$, see Table 2).

In a second single-centre retrospective study, Giovacchini et al. [36] enrolled 358 patients with biochemical recurrence after RP. 11C choline PET-CT was performed in all patients, results were validate by histological analysis, clinical follow-up was reported in patients that underwent salvage radiotherapy. The mean PSA value was $3.77 \mathrm{ng} / \mathrm{ml}$ (range $0.23-45.2 \mathrm{ng} / \mathrm{ml}$ ) and 141 patients had a PSA level $<1.0 \mathrm{ng} / \mathrm{ml}$. The $11 \mathrm{C}$ choline PET-CT resulted positive in $161 / 358$ patients $(45 \%)$ and in 55 patients at prostatectomy bed site. Of these 55 patients, only 32 patients had local recurrence alone, whereas the others had local recurrence associated with nodes or distant metastases. Analysing PET-CT, authors reported an overall sensitivity of $85 \%$, specificity $93 \%$, PPV 91\%, NPV $87 \%$ and accuracy $89 \%$. They found statistically significant correlation between PSA levels and PET-CT results. In particular 19\% of patients with PSA $<1.0 \mathrm{ng} / \mathrm{ml}$ had a positive PET-CT, $46 \%$ of patients with PSA levels between 1.0 and $3.0 \mathrm{ng} / \mathrm{ml}$ had positive results at PET-CT and $82 \%$ of patients with PSA $>3.0 \mathrm{ng} / \mathrm{ml}$ had positive PET-CT results. Patients with positive PET-CT had significantly higher levels of PSA than patients with negative 
PET-CT. The best cut-off value to distinguish between positive and negative PET-CT exams was a PSA of $1.4 \mathrm{ng} / \mathrm{ml}$. For this PSA cut-off sensitivity was $73 \%$ and specificity $72 \%$. The detection rate of positive PET-CT was $24 \%$ with a PSA level $<1.4 \mathrm{ng} / \mathrm{ml}$ and $68 \%$ with a PSA level $>1.4 \mathrm{ng} / \mathrm{ml}$. Authors specified that with a PSA $<1.0 \mathrm{ng} / \mathrm{ml}$ and with a PSA between 3 and $5 \mathrm{ng} / \mathrm{ml}$ the proportions of patients with pathological $11 \mathrm{C}$ choline uptake at prostatectomy bed level were $5 \%$ and $12 \%$, respectively (level of evidence $2 b$, see Table 2 ).

In the third single centre retrospective study Giovacchini et al. [37] from a database of 2124 patients, retrospectively analysed 109 patients with biochemical recurrence, previous RP and pelvic lymph node dissection, no androgen adjuvant therapy, no positive nodes at surgery and no evidence of metastatic disease at conventional imaging. All patients were submitted to $11 \mathrm{C}$ choline PET-CT, with a mean PSA before imaging of $1.31 \mathrm{ng} / \mathrm{ml}$ (range $0.22-16.76 \mathrm{ng} / \mathrm{ml}$ ). They reported positive findings at $11 \mathrm{C}$ choline PET-CT in 12/109 patients, as local recurrence in 4 patients and as pelvic nodal metastases in 8 cases. Authors determined the maximal diameter for nodal lesions (mean $8.7 \mathrm{~mm}$ with a range of 5.4-9.7 mm), but not for prostatectomy bed lesions. Vesicourethral anastomosis biopsy was done in 13 patients: $3 / 13$ had focal choline uptake in the prostatectomy bed and histology was positive for $\mathrm{PC}$ in all 3 patients, 10/13 patients had negative PET-CT results but in 2 of these histology resulted positive for PC.

PSA and PSA velocity were significantly higher in patients with positive PET-CT findings and PSA-DT was significantly shorter in patients with positive PET-CT findings. Overall PET-CT was positive respectively in $5 \%, 15 \%$ and $28 \%$ of patients with PSA between 0.2 and $1.0 \mathrm{ng} / \mathrm{ml}$, between 1.0 and $2.0 \mathrm{ng} / \mathrm{ml}$ and $>2.0 \mathrm{ng} / \mathrm{ml}$. Authors summarised that the resolution of $11 \mathrm{C}$ choline PET-CT, which is about $6 \mathrm{~mm}$, limits the ability to detect small lymph node metastasis and small local recurrences. This contributes to the low positive detection rate of $11 \mathrm{C}$ choline PET-CT and accounts for the 2 patients with false negative findings in the prostatectomy bed compared to biopsy findings (level of evidence $2 b$, Table 2).

In a recent single-centre retrospective study, Castellucci et al. [38] analysed 102 patients with biochemical relapse after RP submitted to $11 \mathrm{C}$ choline PET-CT examination (16 patients were under antiandrogen therapy). They included all patients with a PSA serum level at the time of PET$\mathrm{TC}<1.5 \mathrm{ng} / \mathrm{ml}(0.2-1.5 \mathrm{ng} / \mathrm{ml})$. Choline PET-CT showed positive findings in $28 \%$ of patients (29/102 cases) and local recurrence disease was described in 7 of the 29 positive patients. All suspected local recurrences at PET-CT have been confirmed at TRUS-guided biopsy: 6 patients that were considered negative for local recurrence at PET-CT were found histologically positive for PC recurrence. Regarding local recurrence the sensitivity of $11 \mathrm{C}$ choline PET-CT was $53.8 \%$ and specificity was $100 \%$ (no false positive were recorded). Authors did not reported data on the dimension of the local recurrence lesions. In patients with positive PET-CT the mean PSA-DT was 4.34 months whereas in patients with negative
PET-CT it was 13.3 months. The ROC analysis demonstrated that an optimal cut-off for PSA-DT in prediction of PET-CT results is 7.25 months. Using this value, PSA-DT specificity was $74 \%$, sensitivity $93 \%$, PPV $60 \%$ and NPV $96 \%$ (level of evidence $2 b$, see Table 2 ).

\subsection{Critical analysis and level of evidence for PET-CT}

All these studies were designed in a retrospective way and most of them were single-centre. The number of patients enrolled ranges from 20 to 358 and often the sample size is limited. Another important issue is the value of PSA at PET-CT examination. In the different studies mean PSA level ranges from $0.33 \mathrm{ng} / \mathrm{ml}$ and $5.9 \mathrm{ng} / \mathrm{ml}$ and in most of the studies it is high $(>3 \mathrm{ng} / \mathrm{ml})$. Moreover, in the studies where the mean PSA level is low $(<1.5 \mathrm{ng} / \mathrm{ml})$ the detection rate of PETCT for local recurrence is definitely poor, probably because of PET spatial resolution $(5-6 \mathrm{~mm})$ which does not allow the detection of small lesions. In a review article Picchio et al. [39] affirm that the routine use of choline PET-CT scanning for localisation of the site of $\mathrm{PC}$ recurrence cannot be recommended for PSA values $<1 \mathrm{ng} / \mathrm{ml}$.

A relevant limit of all these studies is also the lack of information on local recurrence dimensions.

In our analysis PET-CT predictive values for PC recurrence or progression after RP show a sensitivity between $60 \%$ and $95 \%$, specificity between $36 \%$ and $93 \%$, PPV between $60 \%$ and $92 \%$, NPV between $61 \%$ and $96 \%$ and accuracy between $78 \%$ and $89 \%$. Unfortunately, from these results is difficult to isolate values referred only to local recurrence detection. Differences in predictive values among the different studies may be related to the different validation criteria used (histologic confirmation of PET-CT findings is rarely available), but also to different PSA values at the imaging examination.

In summary all these studies do not obtain high levels of evidence because of the small sample sizes, the retrospective analysis, the lack of standardised validation criteria and the differences in clinical and pathological samples.

At the same time it is relevant that different studies demonstrate a significant relationship between PET-CT detection rate of recurrence and PSA levels or PSA kinetics (PSA-DT and PSA velocity) at the imaging examination. As proposed by Giovacchini et al. [35] nomograms including the use of PSA and its kinetic can help to better recognize patients candidates to PET-CT scan. Finally we suggest that, according to the results of the reviewed studies, evidences are very low to consider PET-CT as a standard diagnostic tool for early relapse, local recurrence or suspicion of subclinical minimally persistent disease after surgery.

\subsection{Multiparametric MRI}

Of all studies reviewed on the use of multiparametric MRI, we particularly describe 5 articles that appeared to be the most extensive in terms of data on local recurrence following RP. 
All the articles analysed only the aspect of local recurrence after RP.

In a single-centre retrospective study Sella et al. [40] analysed 48 patients with biochemical progression after RP. All patients were submitted to endorectal coil MRI to investigate the presence of a local recurrence of PC. Seven patients showed a negative MRI imaging whereas 41 patients resulted positive for local recurrence at MRI. In 39/41 cases the MRI demonstrated positive imaging in the post-prostatectomy fossa. Of these, 15 patients were submitted to a biopsy that confirmed PC recurrence, 17 patients had a significant reduction of PSA after radiation salvage therapy and 7 patients had a follow-up with MRI that revealed an increase in the size of local recurrence. In the 2/41 patients with a negative MRI, the images demonstrated post-surgical fibrosis. These data resulted in a sensitivity of $95 \%$ and a specificity of $100 \%$ for detection of local relapse at MRI imaging. Authors described also the exact location of the local recurrence: 12 lesions were peri-anastomotic, 17 retrovescical, 9 at seminal vescicle level and 4 lesions were in the anterior and lateral surgical margins. All local recurrences seen on MRI images were isointense to muscle in $\mathrm{T} 1 \mathrm{~W}$ images and slightly hyperintense to muscle in $\mathrm{T} 2 \mathrm{~W}$ images. The mean size of lesions (maximum diameter) was $1.4 \mathrm{~cm}$ (range 0.8-4.5) and the mean PSA of patients before MRI imaging was $2.18 \mathrm{ng} / \mathrm{ml}$ (range $0-10 \mathrm{ng} / \mathrm{ml})$. It is important to underline that 25 patients $(64 \%)$ had a PSA serum level $<1.5 \mathrm{ng} / \mathrm{ml}$ (level of evidence $2 b$, see Table 2).

Casciani et al. [41] in a single centre retrospective study described the use of MRI with DCE in 46 patients previously submitted to RP and with biochemical recurrence. All patients were submitted to both endorectal MRI and DCEMRI. This study particularly analysed the difference between a simple MRI scan and a DCE-MRI. Of all patients, 25 resulted positive for a local recurrence as established using a TRUS guided biopsy in 22 cases and on the basis of a reduction in PSA following salvage radiotherapy in 3 patients. In the 25 positive patients the endorectal MRI showed negative results in 3 patients, 11 patients had dubious findings and 11 patients had positive findings. In the 21 patients without local recurrence, the endorectal MRI showed positive results in 2 patients, dubious results in 8 and negative findings in 11 patients. Therefore MRI correctly classified 23 of 46 patients with an accuracy of $48 \% ; 21$ patients without local recurrence and 12 with local recurrence were correctly classified with a sensitivity of $48 \%$ and a specificity of $52 \%$ (PPV $=54 \%$ and $\mathrm{NPV}=46 \%$ ). The DCE-MRI identified as negative all the 21 patients without local recurrence and identified as positive 22 of 25 patients with local recurrence; the accuracy was $94 \%$, sensitivity was $88 \%$ and specificity was $100 \%$, PPV was $100 \%$ and NPV was $88 \%$. The mean diameter of the lesions was $1.5 \mathrm{~cm}$ (range $0.4-4.0 \mathrm{~cm}$ ) and the mean PSA level was $1.9 \mathrm{ng} / \mathrm{ml}$ (range $0.1-6.0 \mathrm{ng} / \mathrm{ml}$ ). Authors summarised that DCE-MRI improved diagnostic accuracy and is able to better define nodules that appear markedly hyperintense at $\mathrm{T} 2 \mathrm{~W}$ MRI as residual prostatic healthy tissue or fibrotic residual of seminal vesicle or peri-anastomotic scars (level of evidence $2 b$, see Table 2).

In a prospectic single-centre study, Sciarra et al. [42] analysed the accuracy of MRSI and DCE-MRI in the definition of local recurrence after RP in 77 patients divided in three groups. Group A enclosed 47 patients in which, for the higher level of PSA and probable bigger size of local recurrence lesions, a TRUS-guided biopsy was performed to validate MRI results. Group B enclosed 20 patients in which, for the lower level of PSA and probable smaller size of local recurrence, a reduction in PSA ( $>50 \%)$ after salvage radiotherapy was used to validate MRI results. Group C enclosed 10 patients used as control group. In Group A, at MRSI, a local recurrence was correctly observed in 26 of 47 patients, $5 / 47$ were false negative, $14 / 47$ were true negative and 2/47 were false positive. Sensitivity, specificity, PPV, NPV of MRSI resulted 84\%, 88\%, 93\%, 74\%, respectively. In the same group, the analysis with DCE-MRI revealed 22/47 true positive, 9/47 false negative, 15/47 true negative, $1 / 47$ false positive cases. Sensitivity, specificity, PPV, NPV of DCE-MRI were $71 \%, 94 \%, 96 \%, 63 \%$ respectively. The combination of MRSI and DCE-MRI produced 27/47 true positive, $4 / 47$ false negative, $15 / 47$ true negative, $1 / 47$ false positive with a sensitivity of $87 \%$, specificity of $94 \%$, PPV of $96 \%$ and NPV of $79 \%$. In this group the mean PSA value was $1.26 \mathrm{ng} / \mathrm{ml}$ (range $0.9-1.9 \mathrm{ng} / \mathrm{ml}$ ) and the maximal transverse dimension of a lesion representing local recurrence averaged $13.3 \mathrm{~mm}$.

In group B the MRSI analysis showed 10/20 true positive, $4 / 20$ false negative, $5 / 20$ true negative and $1 / 20$ false positive with a sensitivity, specificity, PPV, NPV of $71 \%, 83 \%, 91 \%$, $56 \%$, respectively. The DCE-MRI analysis showed $11 / 20$ true positive, $3 / 20$ false negative, $6 / 20$ true negative and 0 false positive with a sensitivity, specificity, PPV, NPV of $79 \%$, $100 \%, 100 \%, 67 \%$, respectively. The combined MRSI and DCE-MRI analysis showed 12/20 true positive, 2/20 false negative, $6 / 20$ true negative and 0 false positive with a sensitivity, specificity, PPV, NPV of $86 \%, 100 \%, 100 \%, 75 \%$, respectively. The mean PSA level at the time of MRI was $0.8 \mathrm{ng} / \mathrm{ml}$ (range $0.4-1.4 \mathrm{ng} / \mathrm{ml}$ ) and the mean maximal transverse diameter of suspected local recurrence was $6 \mathrm{~mm}$. In the control group any patients resulted positive in all the MRI different studies. All these findings suggest that the combined use of MRSI and DCE-MRI can have a higher diagnostic accuracy, in particular in patients with low PSA serum level and with small volume local disease (level of evidence $2 b$, see Table 2).

Cirillo et al. [43] in a retrospective single-centre study, enrolled 72 patients with a mean PSA serum level of $1.23 \mathrm{ng} / \mathrm{ml}$ (range $0.2-8.8 \mathrm{ng} / \mathrm{ml}$ ) after RP. All patients were submitted to MRI scan with and without contrast enhancement (CE). To validate MRI data they used different clinical parameters: TRUS-guided biopsy, decrease of PSA level following radiotherapy, positive findings at choline PETTC, PSA stability during active surveillance. They found 44 patients positive for PC local recurrence (mean PSA 

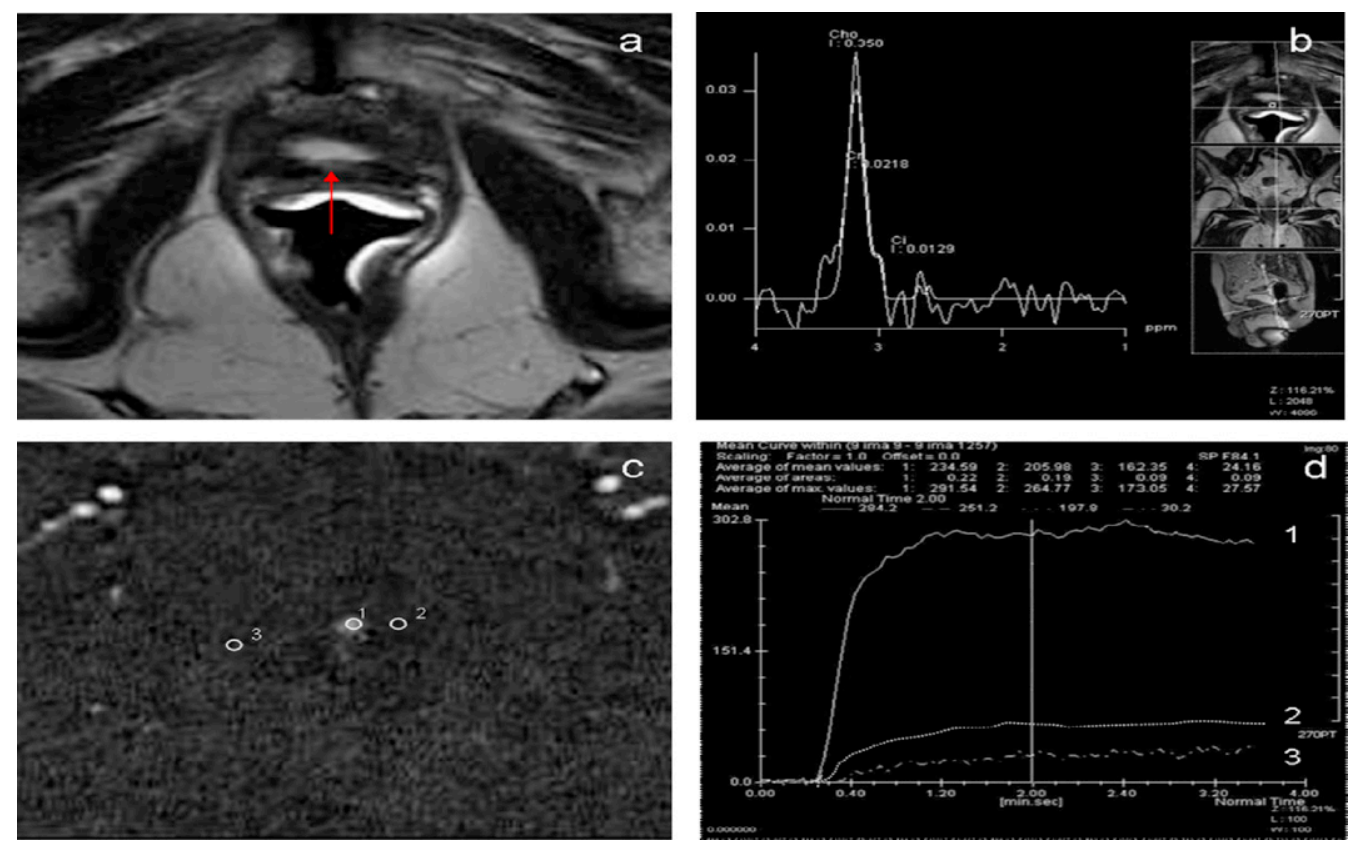

Fig. 1. Case with biochemical progression after radical prostatectomy. PSA level: $0.8 \mathrm{ng} / \mathrm{ml}$. (a) T2-weighted MR images show $5 \mathrm{~mm}$ intermediate-signal intensity nodule (arrow) in a perianastomotic location. (b) MR-Spectroscopy analysis with reference images on the nodule. (c) Dynamic contrast-enhanced (DCE) MRI demonstrates a hypervascular lesion (arrow) and malignant patterns. (d) DCE-MRI intensity/time curve of the same area shows in (c) a hypervascular lesion.

$1.51 \mathrm{ng} / \mathrm{ml}$ ) and 28 negative patients (mean PSA $0.77 \mathrm{ng} / \mathrm{ml}$ ). Using MRI imaging without CE, sensitivity, specificity, PPV, NPV and accuracy for evidencing a local recurrence were $61.4 \%, 82.1 \%, 84.4 \%, 57.5 \%$ and $69.4 \%$, respectively. Authors showed that the diameter of the local recurrences detected varied from 0.8 to $4.2 \mathrm{~cm}$ (average $1.9 \mathrm{~cm}$ ). Using MRI imaging with CE, sensitivity was $84.1 \%$, specificity was $89.3 \%$, PPV $92.5 \%$, NPV $78.1 \%$ and accuracy was $86.1 \%$. At CE-MRI the diameter of the sites of local recurrence detected varied from 0.8 to $3.5 \mathrm{~cm}$ (average 1.7). This comparison showed a statistically significant lower diagnostic accuracy of unenhanced MRI in comparison with CE-MRI, a statistically significant lower sensitivity but no significant specificity differences. Authors moreover asserted that CE-MRI is able to better differentiate between tumour relapse and postoperative scar tissue of fibrosis. They also underlined that $75.6 \%$ of patients with positive findings had a PSA $<1.5 \mathrm{ng} / \mathrm{ml}$ (level of evidence $2 b$, see Table 2).

Panebianco et al. [44] reported the first single-centre comparative study of MRI and PET-CT in the early detection of local recurrence after RP. They enrolled 84 patients with biochemical recurrence after RP using both $18 \mathrm{~F}$ choline PET-CT and MRI (MRSI and DCE-MRI) with a 3 Tesla (T) magnet. On the basis of the used validation criteria, patients were divided in two groups. Group A included 28 patients with $>50 \%$ PSA reduction following radiation therapy used as validation criteria. This group showed an average size of lesions of $6 \mathrm{~mm}$ (range 5-7.2 $\mathrm{mm}$ ) and a mean PSA of $1.1 \mathrm{ng} / \mathrm{ml}$ (range $0.8-1.4 \mathrm{ng} / \mathrm{ml}$ ). Group B included 56 patients with a lesion average size of $13.3 \mathrm{~mm}$ (range
7.6-19.4 mm), mean PSA $1.9 \mathrm{ng} / \mathrm{ml}$ (range $1.3-2.5 \mathrm{ng} / \mathrm{ml}$ ) and TRUS-guided biopsy used as validation criteria. In Group A results in identifying a local recurrence demonstrated for multiparametric MRI a sensitivity of $92 \%$, specificity of $75 \%$, PPV of $96 \%$, NPV $60 \%$ and accuracy of $89 \%$ and for PET-CT a sensitivity of $62 \%$, specificity of $50 \%$, PPV of $88 \%$, NPV $18 \%$ and accuracy of $60 \%$. In Group B results in identifying a local recurrence showed for multiparametric MRI a sensitivity of $94 \%$, specificity of $100 \%$, PPV of $100 \%$, NPV 57\% and accuracy of $94 \%$ and for PET-CT a sensitivity of $92 \%$, specificity of $37 \%$, PPV of $98 \%$, NPV $43 \%$ and accuracy of $91 \%$. PET-CT revealed distant metastases in 25 patients of Group $\mathrm{B}$ and in 5 patients of Group A. Authors compared also the MRI results of this study obtained with a 3 T MRI with those of a previous study using a 2 T MRI (18226441). The use of a $3 \mathrm{~T}$ magnet improved results of MRI in terms of sensitivity and specificity in patients of Group B and of specificity in patients of Group A. They concluded that MRSI-DCE-MRI combined techniques is a valid tool to detect local recurrence following RP and it is more accurate than PET-CT in the identification of smaller lesions in patients with low biochemical failure (PSA $<2 \mathrm{ng} / \mathrm{ml}$ ) (level of evidence $2 \mathrm{~b}$, see Table 2 ).

\subsection{Critical analysis and level of evidence for multiparametric MRI}

Most of the studies using multiparametric MRI were designed in a retrospective way and they were single-centre. The number of patients enrolled in these studies ranges from 46 to 84 and therefore sample size is always limited. Mean 


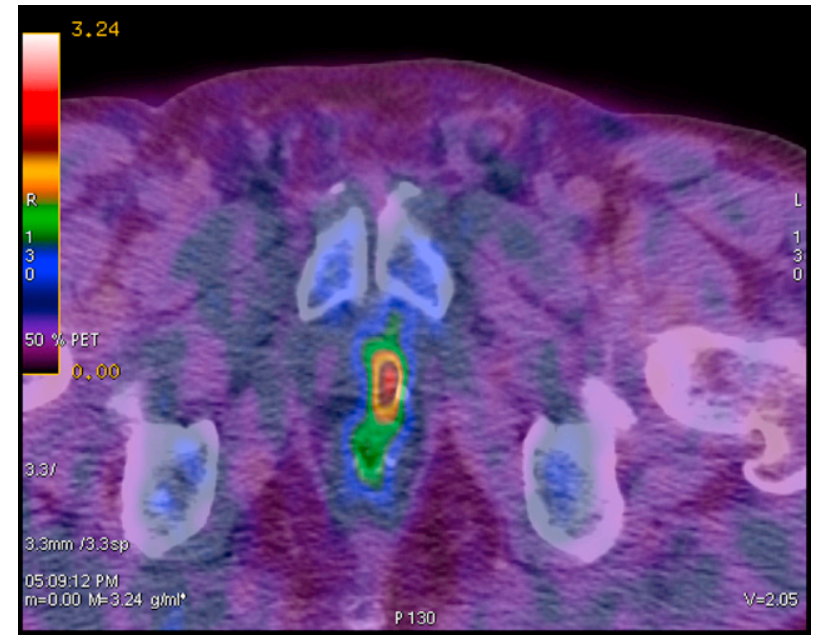

Fig. 2. F 18 choline fused PET-CT axial views show pathological uptake at the left level of the prostate bed in a case submitted to radical prostatectomy with biochemical progression $(\mathrm{PSA}=1.5 \mathrm{ng} / \mathrm{ml})$.

PSA level ranges from $0.8 \mathrm{ng} / \mathrm{ml}$ and $2.18 \mathrm{ng} / \mathrm{ml}$; therefore in the MRI studies PSA levels at inclusion are definitely lower if compared with those in PET-CT studies. This is a fundamental aspect related to the need of an early diagnosis of low dimension local recurrences. MRI studies show values of sensitivity between $84 \%$ and $95 \%$, specificity between $75 \%$ and $100 \%$, PPV between $92 \%$ and $100 \%$, NPV between $57 \%$ and $88 \%$ and accuracy between $86 \%$ and $94 \%$. The mean diameter of local recurrence lesions is always described in these studies and ranges from $6 \mathrm{~mm}$ and $15 \mathrm{~mm}$.

In summary, we found a limited number of studies on the use of MRI for the detection of local recurrence following RP. The level of evidence is not very high because of the small sample sizes, the retrospective analysis and the lack of standardised validation criteria.

Overall MRI seems to have a high detection rate for local recurrence also in patients with low PSA levels and with small volume recurrent diseases, in particular using the combined modality of MRSI and DCE-MRI. The $3 \mathrm{~T}$ magnet, even if it has been used only in the recent study of Panebianco et al. [44], could offer promising better results associated to his higher spatial resolution. According to the reviewed studies we suggest that multiparametric MRI can be a valid diagnostic tool for the early biochemical failure or suspicion of subclinical minimally persistent disease following RP, able to detect local recurrence in patients with low PSA levels $(<1.5 \mathrm{ng} / \mathrm{ml})$. However, larger prospective studies should better confirm these evidences.

\section{Conclusions}

The problem of local recurrence after radical prostatectomy is topical because of its high frequency. We know the relevance to have a very rapid diagnosis in terms of PSA and also a sure localization of the recurrence. All the most important guidelines of urological and oncological societies do not have significant recommendations regarding the use of specific imaging techniques for the early diagnosis of local recurrence after RP. The NCCN guidelines [45] provide the use of different imaging techniques as PET, MRI, CT and AUA guidelines [46] do not have specific recommendations for the use of imaging in patients with biochemical relapse and possibility to have local recurrence after RP. EAU guidelines [47] indicate PET-CT and MRI as possible tools in patients with PSA recurrence between 1.0 and $2.0 \mathrm{ng} / \mathrm{ml}$, but they are not considered as routine procedures.

Published data indicate an emerging role for multiparametric MRI and for PET-CT in different aspects of PC management. Even if few studies are available, they suggest for MRI a significant detection rate for local recurrence also with very low PSA serum levels, in particular with the combined use of MRSI and DCE-MRI. The 3T modality can again improve the spatial resolution and scanning conditions even at very low PSA values, so to detect very small tumours (Fig. 1: a case).

PET-CT scanning, in particular with the use of choline, can provide a systemic localisation of the site of PC recurrence in a single step (Fig. 2: a case). On the basis of published data this procedure cannot be recommended for routine use to specifically detect local recurrence, particularly in patients with low level of PSA $(<1.5 \mathrm{ng} / \mathrm{ml})$. At the same time we can assert that PET-CT could be indicated when PSA-DT is $<3 / 6$ months and PSA velocity is very high; in these situations patients have a high risk of nodal micrometastases and PET-CT has higher detection rate if compared with multiparametric MRI [48].

Only one study with a direct comparison between multiparametric MRI and PET-CT in the same population has been produced (44). Moreover the level of evidence provides from all the studies in the literature is not very high. For these reasons more prospective comparative studies and larger multicentre trials are needed to confirm promising results of these two techniques and to establish guidelines for the imaging in patients with biochemical failure after RP.

\section{Conflict of interest}

None of the authors has any financial or personal relationships with organizations that could inappropriately influence the work.

\section{Funding}

None of the authors has a funding source for the work.

\section{Reviewers}

Cosimo De Nunzio, MD PhD, University, Department of Urology, Ospedale Sant'Andrea, Rome, Italy. 
Theo M. de Reijke, MD PhD FEBU, Urologist, Academic Medical Center, Urology, Meibergdreef 9, NL-1105 AZ Amsterdam, Netherlands.

Jean-Pierre Papazyan, MD FMH, Clinique de Genolier, Nuclear Medicine, 1 route du Muids, CH-1272 Genolier, Switzerland.

\section{References}

[1] Bill-Axelson A, Holmberg L, Filén F, et al. Scandinavian Prostate Cancer Group Study Number 4. Radical prostatectomy versus watchful waiting in localized prostate cancer: the Scandinavian prostate cancer group-4 randomized trial. J Natl Cancer Inst 2008;100(August (16)):1144-54 [Epub 2008 August 11].

[2] Bianco Jr FJ, Scardino PT, Eastham JA. Radical prostatectomy: longterm cancer control and recovery of sexual and urinary function ("trifecta"). Urology 2005;66(November (5 Suppl.)):83-94.

[3] Freedland SJ, Presti Jr JC, Amling CL, et al. SEARCH Database Study Group. Time trends in biochemical recurrence after radical prostatectomy: results of the SEARCH database. Urology 2003;61(April (4)):736-41.

[4] Han M, Partin AW, Zahurak M, Piantadosi S, Epstein JI, Walsh PC. Biochemical (prostate specific antigen) recurrence probability following radical prostatectomy for clinically localized prostate cancer. J Urol 2003;169(February (2)):517-23.

[5] Grossfeld GD, Stier DM, Flanders SC, et al. Use of second treatment following definitive local therapy for prostate cancer: data from the caPSURE database. J Urol 1998;160(October (4)):1398-404.

[6] Freedland SJ, Humphreys EB, Mangold LA, Eisenberger M, Partin AW. Time to prostate specific antigen recurrence after radical prostatectomy and risk of prostate cancer specific mortality. J Urol 2006;176(October (4 Pt 1)):1404-8.

[7] Pound CR, Partin AW, Eisenberger MA, Chan DW, Pearson JD, Walsh PC. Natural history of progression after PSA elevation following radical prostatectomy. JAMA 1999;281(May (17)):1591-7.

[8] Moul JW. Prostate specific antigen only progression of prostate cancer. J Urol 2000;163(June (6)):1632-42.

[9] Amling CL, Bergstralh EJ, Blute ML, Slezak JM, Zincke H. Defining prostate specific antigen progression after radical prostatectomy: what is the most appropriate cut point? J Urol 2001;165(April (4)):1146-51.

[10] Stephenson AJ, Kattan MW, Eastham JA, et al. Defining biochemical recurrence of prostate cancer after radical prostatectomy: a proposal for a standardized definition. J Clin Oncol 2006;24(August (24)):3973-8.

[11] Roach 3rd M, Hanks G, Thames Jr H, et al. Defining biochemical failure following radiotherapy with or without hormonal therapy in men with clinically localized prostate cancer: recommendations of the RTOGASTRO Phoenix Consensus Conference. Int J Radiat Oncol Biol Phys 2006;65(July (4)):965-74.

[12] Marks RA, Koch MO, Lopez-Beltran A, Montironi R, Juliar BE, Cheng $\mathrm{L}$. The relationship between the extent of surgical margin positivity and prostate specific antigen recurrence in radical prostatectomy specimens. Hum Pathol 2007;38(August (8)):1207-11 [Epub 2007 May 8].

[13] Stephenson AJ, Scardino PT, Kattan MW, et al. Predicting the outcome of salvage radiation therapy for recurrent prostate cancer after radical prostatectomy. J Clin Oncol 2007;25(May (15)):2035-41.

[14] Boccon-Gibod L, Djavan WB, Hammerer P, et al. Management of prostate-specific antigen relapse in prostate cancer: a European Consensus. Int J Clin Pract 2004;58(April (4)):382-90.

[15] King CR, Spiotto MT. Improved outcomes with higher doses for salvage radiotherapy after prostatectomy. Int J Radiat Oncol Biol Phys 2008;71(May (1)):23-7 [Epub 2008 Jan 22].

[16] Scattoni V, Roscigno M, Raber M, et al. Multiple vesico-urethral biopsies following radical prostatectomy: the predictive roles of TRUS,
DRE, PSA and the pathological stage. Eur Urol 2003;44(October (4)):407-14.

[17] Kane CJ, Amling CL, Johnstone PA, Pak N, et al. Limited value of bone scintigraphy and computed tomography in assessing biochemical failure after radical prostatectomy. Urology 2003;61(March (3)):607-11.

[18] Parsons KF, Irani J, Fall M, et al. European Association of urology guidelines; 2011.

[19] Zeisel SH. Dietary choline: biochemistry, physiology, and pharmacology. Annu Rev Nutr 1981;1:95-121.

[20] Ackerstaff E, Pflug BR, Nelson JB, Bhujwalla ZM. Detection of increased choline compounds with proton nuclear magnetic resonance spectroscopy subsequent to malignant transformation of human prostatic epithelial cells. Cancer Res 2001;61(May (9)):3599-603.

[21] Sutinen E, Nurmi M, Roivainen A, et al. Kinetics of [(11)C]choline uptake in prostate cancer: a PET study. Eur J Nucl Med Mol Imaging 2004;31(March (3)):317-24 [Epub 2003 Nov 20].

[22] Souvatzoglou M, Weirich G, Schwarzenboeck S, et al. The sensitivity of [11C]Choline PET/CT to localize prostate cancer depends on the tumor configuration. Clin Cancer Res 2011;17(June (11)):3751-9 [Epub 2011 April 14].

[23] McNeal JE. The zonal anatomy of the prostate. Prostate 1981;2(1):35-49.

[24] Knopp MV, Giesel FL, Marcos H, von Tengg-Kobligk H, Choyke P. Dynamic contrast-enhanced magnetic resonance imaging in oncology. Top Magn Reson Imaging 2001;12(August (4)):301-8.

[25] Somford DM, Fütterer JJ, Hambrock T, Barentsz JO. Diffusion and perfusion MR imaging of the prostate. Magn Reson Imaging Clin N Am 2008;16(November (4)):685-95, ix.

[26] Seitz M, Shukla-Dave A, Bjartell A, et al. Functional magnetic resonance imaging in prostate cancer. Eur Urol 2009;55(April (4)):801-14 [Epub 2009 Jan 21].

[27] Fuchsjäger M, Akin O, Shukla-Dave A, Pucar D, Hricak H. The role of MRI and MRSI in diagnosis, treatment selection, and post-treatment follow-up for prostate cancer. Clin Adv Hematol Oncol 2009;7(March (3)):193-202.

[28] Kirkham AP, Emberton M, Allen C. How good is MRI at detecting and characterising cancer within the prostate? Eur Urol 2006;50(December (6)):1163-74, discussion 1175 [Epub 2006 Jun 30].

[29] Heinisch M, Dirisamer A, Loidl W, et al. Positron emission tomography/computed tomography with F-18-fluorocholine for restaging of prostate cancer patients: meaningful at PSA $<5 \mathrm{ng} / \mathrm{ml}$ ? Mol Imaging Biol 2006;8(January-February (1)):43-8.

[30] Rinnab L, Mottaghy FM, Blumstein NM, et al. Evaluation of [11C]choline positron-emission/computed tomography in patients with increasing prostate-specific antigen levels after primary treatment for prostate cancer. BJU Int 2007;100(October (4)):786-93.

[31] Vees H, Buchegger F, Albrecht S, et al. 18F-choline and/or 11C-acetate positron emission tomography: detection of residual or progressive subclinical disease at very low prostate-specific antigen values $(<1 \mathrm{ng} / \mathrm{mL})$ after radical prostatectomy. BJU Int 2007;99(June (6)):1415-20 [Epub 2007 Apr 8].

[32] Reske SN, Blumstein NM, Glatting G. $\left[{ }^{11} \mathrm{C}\right]$ choline PET/CT imaging in occult local relapse of prostate cancer after radical prostatectomy. Eur J Nucl Med Mol Imaging 2008;35(January (1)):9-17 [Epub 2007 Sep 9].

[33] Rinnab L, Simon J, Hautmann RE, et al. [(11)C]choline PET/CT in prostate cancer patients with biochemical recurrence after radical prostatectomy. World J Urol 2009;27(October (5)):619-25 [Epub 2009 Feb 21].

[34] Castellucci P, Fuccio C, Nanni C, et al. Influence of trigger PSA and PSA kinetics on 11C-Choline PET/CT detection rate in patients with biochemical relapse after radical prostatectomy. J Nucl Med 2009;50(September (9)):1394-400 [Epub 2009 Aug 18].

[35] Giovacchini G, Picchio M, Scattoni V, et al. PSA doubling time for prediction of $[(11) \mathrm{C}]$ choline PET/CT findings in prostate cancer patients with biochemical failure after radical prostatectomy. Eur J Nucl Med Mol Imaging 2010;37(June (6)):1106-16 [Epub 2010 Mar 20]. 
[36] Giovacchini G, Picchio M, Briganti A, et al. [11C]choline positron emission tomography/computerized tomography to restage prostate cancer cases with biochemical failure after radical prostatectomy and no disease evidence on conventional imaging. J Urol 2010;184(September (3)):938-43.

[37] Giovacchini G, Picchio M, Coradeschi E, et al. Predictive factors of [(11)C]choline PET/CT in patients with biochemical failure after radical prostatectomy. Eur J Nucl Med Mol Imaging 2010;37(February (2)):301-9 [Epub 2009 Sep 15].

[38] Castellucci P, Fuccio C, Rubello D, et al. Is there a role for ${ }^{11} \mathrm{C}$-choline PET/CT in the early detection of metastatic disease in surgically treated prostate cancer patients with a mild PSA increase $<1.5 \mathrm{ng} / \mathrm{ml}$ ? Eur J Nucl Med Mol Imaging 2011;38(January (1)):55-63 [Epub 2010 Sep 17].

[39] Picchio M, Briganti A, Fanti S, et al. The role of choline positron emission tomography/computed tomography in the management of patients with prostate-specific antigen progression after radical treatment of prostate cancer. Eur Urol 2011;59(January (1)):51-60 [Epub 2010 Sep 15].

[40] Sella T, Schwartz LH, Swindle PW, et al. Suspected local recurrence after radical prostatectomy: endorectal coil MR imaging. Radiology 2004;231(May (2)):379-85 [Epub 2004 Apr 2].

[41] Casciani E, Polettini E, Carmenini E, et al. Endorectal and dynamic contrast-enhanced MRI for detection of local recurrence after radical prostatectomy. AJR Am J Roentgenol 2008;190(May (5)):1187-92.

[42] Sciarra A, Panebianco V, Salciccia S, et al. Role of dynamic contrast-enhanced magnetic resonance (MR) imaging and proton MR spectroscopic imaging in the detection of local recurrence after radical prostatectomy for prostate cancer. Eur Urol 2008;54(September (3)):589-600 [Epub 2007 Dec 31].

[43] Cirillo S, Petracchini M, Scotti L, et al. Endorectal magnetic resonance imaging at 1.5 Tesla to assess local recurrence following radical prostatectomy using T2-weighted and contrast-enhanced imaging. Eur Radiol 2009;19(March (3)):761-9 [Epub 2008 Sep 30].

[44] Panebianco V, Sciarra A, Lisi D, et al. Prostate cancer: 1HMRSDCEMR at 3T versus [(18)F]choline PET/CT in the detection of local prostate cancer recurrence in men with biochemical progression after radical retropubic prostatectomy (RRP). Eur J Radiol 2011;(February) [Epub ahead of print].
[45] NCCN guidelines Version 4. 2011 Panel Members Prostate Cancer.

[46] American Urological Association. Prostate cancer clinical guideline update panel members and consultants; 2007.

[47] Heidenreich A, Bolla M, Jomiau S, et al. European Association of Urology guidelines on prostate cancer; 2011.

[48] Scattoni V, Picchio M, Suardi N, et al. Detection of lymph-node metastases with integrated [11C]choline PET/CT in patients with PSA failure after radical retropubic prostatectomy: results confirmed by open pelvic-retroperitoneal lymphadenectomy. Eur Urol 2007;52(August (2)):423-9 [Epub 2007 Mar 20].

\section{Biography}

Alessandro Sciarra, medical doctor, received his title of specialist in Urology in the School of Urology, University Sapienza of Rome, Italy. Now he is working in the Department of Urology "U. Bracci" of the University Sapienza of Rome and is responsible for a Prostate Unit there. He is currently a Professor in Medicine either for the School of Medicine or for the Schools of Urology and Nephrology at the University Sapienza of Rome. He has been member of the scientific committee of the Italian Society of Urology (SIU); referee for the European Association of Urology (EAU) and the European Urology Journal. His scientific activity has been published in the form of 109 contributions to various indexed international journals, most of them as the first author, and has edited three books. He has been an investigator or primary investigator in different international trials, in particular in urological oncology and benign prostatic hypertrophy, and he is a manuscript reviewer for a number of international journals. Current areas of research interest include urological oncology, mainly prostate cancer and kidney cancer, either as basic research or clinical studies. 